\title{
Everyday Transcendence? \\ Robert Musil, William James, and Mysticism
}

\author{
RITCHIE ROBERTSON
}

\section{Introduction: The Revival of Mysticism}

At the turn of the nineteenth to the twentieth century, Germany saw a renewed interest in mysticism. This can be understood as a response to two phenomena. First, the official doctrine of the Churches, despite their strong position in the state, was discredited in the eyes of most intellectuals by the progress of the Higher Criticism from the Enlightenment onwards; while since Friedrich Schleiermacher's Reden über die Religion (Lectures on Religion, 1799) the Protestant Churches had surrendered the questionable intellectual content of theology and taken their stand instead on the irrefutable, but also unprovable, ground of religious feeling. Second, late nineteenthcentury Germany accepted the authority of science, understanding thereby the grimly factual positivist and materialist science espoused by Ludwig Büchner in the widelyread treatise Kraft und Stoff (Force and Matter, 1855). But science could not answer the desire for meaning in life. Hence the popularity of Schopenhauer, whose pessimism seemed entirely compatible with the vulgarised Darwinian doctrine of the struggle for existence. Hence also a search for forms of experience that slipped through the iron grid of scientific materialism. Such experience might be the Dionysian sensation of unity with one's fellow-humans that Nietzsche described as the experience of tragedy. It might be an apprehension of the unity of life encouraged by scientific monism. An experience of this kind seems to be evoked in the quasimystical moments in Thomas Mann's Buddenbrooks when the presence of the sea suggests the loss of normal boundaries, as when Hanno spends his holidays at the seaside: 'a mild narcosis ('Betäubung'), in which consciousness of time and space and everything limited was blissfully swallowed up'. ${ }^{1}$

Past mystical writers were read with enthusiasm. Wilhelm Bölsche, a leading Naturalist writer specialising in popular science, also republished the mystical aphorisms of Angelus Silesius; Kafka read Meister Eckhart; Hofmannsthal quoted from the Persian Sufi mystic Jalal al-Din Rumi. Access to the classics of mysticism was provided especially by Martin Buber, who compiled an anthology of mystical testimonies from around the world, Ekstatische Konfessionen, which was of particular interest to Musil. $^{2}$

\section{William James on Mysticism}

Before proceeding further, however, we need to ask about the meaning of the word 'mysticism'. Is there some danger of its meaning being stretched to cover every kind of preternatural experience, irrespective of cultural and historical contexts? Fortunately, we have a guide from the period under discussion, in the person of William James. His Gifford Lectures on Natural Religion, delivered at Edinburgh in

\footnotetext{
${ }^{1}$ Thomas Mann, Buddenbrooks. Verfall einer Familie, ed. by Eckhard Heftrich (Frankfurt a.M.: Fischer, 2002), p. 696. My translation.

${ }^{2}$ See Dietmar Goltschnigg, Mystische Tradition im Roman Robert Musils: Martin Bubers 'Ekstatische Konfessionen' im 'Mann ohne Eigenschaften' (Heidelberg: Stiehm, 1974), and more generally, Uwe Spörl, Gottlose Mystik in der deutschen Literatur um die Jahrhundertwende (Paderborn: Schöningh, 1997).
} 
1901-02 and published as The Varieties of Religious Experience, include a famous chapter headed 'Mysticism'. Here James, following his usual practices, quotes a great variety of written testimonies by people who have had mystical experiences. His authorities, in the earlier part of the chapter, range from Martin Luther to the Victorian art historian John Addington Symonds, from Malwida von Meysenbug to Walt Whitman. He discusses also the changes in consciousness brought about by alcohol, drugs, and anaesthetics. One conclusion he draws is that alongside our normal waking consciousness there lie many different forms of consciousness, potentially available to us, and separated from our normal awareness only by a thin screen.

Mystical states of consciousness, or mystical experiences, can be distinguished from others by four characteristics. First, the mystical experience is ineffable. No words are remotely adequate to say what it was like. It is more like an emotional than an intellectual state. Yet, and in some tension with this, the second characteristic of mystical experience is its 'noetic' quality. To the person who has it, it feels like a state of knowledge, a revelation of truth, and yet the truth that the mystic apprehends cannot be expressed in words. This in no way diminishes the authority of the revelation. Its impact is superior to that of any merely verbal formulation. Thirdly, James says, mystical states are brief. They cannot be sustained beyond half an hour, or an hour or so at the very most. And, fourthly, they are passive. There are techniques by which they can be induced or encouraged, yet once the mystical experience is there, the mystic feels that his own will is in suspension, and often as if he is passively in the grip of a superior power.

Having offered his outline definition of mysticism, and quoted a number of testimonies, James turns his attention to those religious traditions in which mystical consciousness is deliberately cultivated. He talks about the systematic mystical training practised in Hinduism under the name of yoga, and the sequence of higher contemplative states recognised in Buddhism. He mentions Sufi mysticism, which was then beginning to become known in the West, quoting from a French translation of the autobiography by the eleventh-century Persian mystic and scholar Al-Ghazzali. But he understandably gives most attention to the mystical traditions within Christianity. These exist especially within Roman Catholicism, where, despite the official Church's suspicion of mystics, there is a well-established practice of meditation designed to elevate the soul towards God. James illustrates this tradition by quoting from St John of the Cross, St Teresa of Ávila, and St Ignatius of Loyola. He notes with surprise that, by contrast, Protestantism has abandoned the cultivation of mystical prayer:

Through the practice of orison the higher levels of mystical experience may be attained. It is odd that Protestantism, especially evangelical Protestantism, should seemingly have abandoned everything methodical in this line. Apart from what prayer may lead to, Protestant mystical experience appears to have been almost exclusively sporadic. $^{3}$

This observation is important, because the German writers who showed an interest in mysticism came from backgrounds which were either Protestant (as with Nietzsche, whose father was a Lutheran clergyman), non-religious, or Jewish with a strong tendency towards Protestant-style rationalism. It was in reaction against Hermann

\footnotetext{
${ }^{3}$ William James, The Varieties of Religious Experience (London: Longmans, Green, and Co., 1902), p. 334.
} 
Cohen, the philosopher who tried to rethink Judaism along rationalist and quasiProtestant lines, that Martin Buber embarked on his rediscovery of Hasidic mysticism. Hence the mystical experiences reported or explored by German writers around the turn of the century tend, precisely, to be sporadic and occasional. They are not part of any programme of meditation or contemplation. They come unbidden and vanish again, though they leave behind a powerful memory.

\section{Epiphanies}

These mystical experiences are epiphanies, as described in a classic essay by Theodore Ziolkowski that examines texts by James Joyce, Hugo von Hofmannsthal, Robert Musil and Franz Kafka. ${ }^{4}$ One such epiphany is the mystical experience recorded by Rilke in his essay 'Erlebnis' ${ }^{5}$ The speaker (the experience is recounted in the third person) is leaning in the fork of a tree and contemplates nature so deeply that he feels fully immersed in it, 'völlig eingelassen in die Natur'; his body feels suddenly porous, able to absorb a degree of influence ('einen Grad von Einfluß') that would not normally be possible. During this experience, the speaker is still able to ask himself what is happening, and finds the formualtion that he has arrived on the other side of nature ('er sei auf die andere Seite der Natur geraten'). In this state, a casual object, a flower, seems full of inexhaustible but also ineffable meaning:

A periwinkle near him, whose blue gaze he had often met before, now touched him from a more intellectual distance, but with such inexhaustible significance as though there were nothing more to hide. ${ }^{6}$

Mystical experience is a major theme of Musil's early novel, Die

Verwirrungen des Zöglings Törleß. It takes the form partly of epiphanies which, given the strongly autobiographical content of the novel, we can assume to be based on his own experience. One of these occurs to the schoolboy Törless when he is lying on his back, looking up at the sky, and suddenly apprehends the real meaning of the word, so often tossed about in maths lessons, 'infinity':

And suddenly he noticed — he felt as if it were the first time it had happened — how high the sky actually was.

He felt a kind of sense of alarm. Right above him an unutterably deep little blue hole was shining between the clouds.

It seemed to him as if you ought to be able to climb up into it on a long, long ladder. But the farther he went into it, pulling himself up with his eyes, the more the shining blue background receded. And yet it seemed as if you ought to be able to reach it and hold it fast with your gaze. The desire to do so grew intense to the point of torment.

It was as if his vision, strained to the utmost, were shooting looks like arrows between the clouds and as if, however far away it set its aim, they always fell a little short. $^{7}$

\footnotetext{
${ }^{4}$ Theodore Ziolkowski, 'James Joyces Epiphanie und die Überwindung der empirischen Welt in der modernen deutschen Prosa', Deutsche Vierteljahrsschrift, 35 (1961), 594-616.

${ }^{5}$ Rainer Maria Rilke, Werke, 4 vols, ed. Manfred Engel et al. (Frankfurt a.M. and Leipzig: Insel, 1996), vol. 4, pp. 666-8.

${ }^{6}$ Ibid., p. 668. My translation.
} 
This - rather unwelcome - epiphany is associated, not by chance, with mathematics. Musil was trained initially as a mathematician and engineer. After his passing his exams in engineering in 1901, he taught for a year at the Technical College in Stuttgart. From this period date his first published works, which dealt with machinery and the heating of domestic interiors. Musil also invented a colour-wheel, an instrument which measured people's perception of light; it was patented as the 'Musil colour-wheel'. Musil left Stuttgart in 1903 and studied for the next five years in Berlin, where he graduated in philosophy, physics and mathematics. He wrote a thesis on the philosopher and psychologist Ernst Mach, but though he could have adopted an academic career like his father, he chose instead to become a freelance writer and remained one for the rest of his life, chiefly in Vienna though with intervals in Berlin.

With his scientific outlook, Musil is the last person one would have expected to take an interest in mysticism. ${ }^{8} \mathrm{He}$ did so, however, and he was convinced that there was no need to talk about mysticism in the helplessly emotional language common at the turn of the century. Mystical experiences could not be put into words. But one could talk about them, map their contours, with as much precisions as when talking about other psychological states. Moreover, in the novel, Törless's experience of infinity is connected in obscure ways with a range of other experiences which he has difficulty in making sense of. Many of them are linked with sexuality. Like other boys at his school, he visits from time to time a local prostitute; he feels sex with her to be furtive and dirty, and he contrasts her with his mother, who is to him a pure, radiant, sexless being. Yet he also knows that both the prostitute and his mother share femininity and sexuality. The puzzle for him is how such utterly different worlds, the degraded world of the prostitute and the pure world of his home, can both exist in the same world. Sexuality also enters into his relations with his fellow-schoolboys. Two older boys and he meet from time to time in a secret room among the school's attics. There they entice another boy, Basini, who has been caught stealing; they blackmail him, and the two other boys beat him and sodomise him, while Törless looks on in bemused disgust. His reaction is not moral condemnation but an essentially aesthetic dislike of their crudity and a puzzlement about how the gross and brutal practices in the secret room can coexist with the orderly, lighted world of the classrooms. These external spaces - the prostitute's hovel, the secret room, the clarity of the classrooms and of Törless's home - serve also as metaphors for Törless's interior space. He cannot cope with the diversity of feelings, thoughts, and sensations that exist side by side in his psyche. In articulating Törless's confusion, Musil was especially helped by the writings of the Belgian symbolist Maurice Maeterlinck. He gave his novel an epigraph from Maeterlinck which laments the inadequacy of language to express our inner experience. And Törless's sense of a dark, ungraspable world somewhere within him corresponds to a passage from Maeterlinck such as the following: 'We live at a distance from our true life and we feel that even our profoundest and most intimate thoughts do not concern us, for we are something other than our thoughts and dreams. And it is only at certain moments, almost by accident, that we live our own life.' 9

\footnotetext{
${ }^{7}$ Robert Musil, The Confusions of Young Törless, trans. by Mike Mitchell, Oxford World's Classics (Oxford: Oxford University Press, 2014), pp. 67-68.

${ }^{8}$ Amid the large secondary literature on Musil, an excellent guide to this subject is still Elisabeth Albertsen, Ratio und Mystik im Werk Robert Musils (Munich: Nymphenburger Verlagshandlung, 1968).

${ }^{9}$ Maurice Maeterlinck, Le trésor des humbles (Brussels: Éditions Labor, 1986), p. 41. My translation.
} 
At the end of the novel, Törless, facing a group of uncomprehending teachers, is suddenly inspired to find words with which to describe his strange experiences. As he begins his speech, he looks out of the window and sees a crow sitting on a branch, silhouetted against a featureless snowy expanse; this represents, as Elisabeth Stopp observes, 'the kind of clear-cut, black-and-white certainty that he has now reached, as sharply etched as the dark bird against the snow'. ${ }^{10}$ He puts his experiences into the clearest words available for what is essentially ineffable:

I can't put it in any other way than to say that I see things in two forms. All things, thoughts included. [...]Just as I feel that a thought comes to life inside me, I also feel that something inside me is alive at the sight of things, when thoughts are silent. There is inside me, among all the thoughts, something dark that I cannot quantify with my thoughts, a life that is not expressed in words and that is yet my life... ${ }^{11}$

The epiphanic experiences reported by Rilke, Musil, and many others are, if not post-religious, at any rate post-Christian. The term 'mysticism', applied to them, indicates dissatisfaction with the narrow conception of reality held by positivistic science, rather than any authentic return to the mysticism of earlier centuries. While Christian mysticism has traditionally offered a form of non-rational cognition or knowledge of God ('Erkenntnis'), modern mysticism corresponds to postSchleiermacher interpretations of Christianity in emptying out the cognitive content and trying to fill the gap with emotion. It offers an experience ('Erlebnis'), in the heavily charged sense that the philosopher Wilhelm Dilthey gave to that term. Dilthey shared the positivist and Nietzschean disbelief in metaphysics. His starting-point, 'life', was not remote and abstract; it was immediate and concrete, and known best in moments of intense experience ('Erlebnis'). On this concept Dilthey based a critical theory which gave a supreme place to 'Erlebnislyrik', the poetry, typified by the lyrics of the young Goethe, in which moments of heightened experience were preserved and transmitted to readers.

Similarly, Martin Buber, inspired both by Dilthey and by Nietzsche's account of Dionysiac intoxication in The Birth of Tragedy, claims that the essence of mysticism is the experience of ecstasy. In the preface to his anthology Ekstatische Konfessionen he defines ecstasy, in keeping with its Greek etymology, as 'Hinaustreten', 'stepping outside' of one's normal experience. ${ }^{12}$ He calls it an experience which cannot be analysed, still less explained away in psychological or physiological terms. All he can say about it is that it dissolves the barriers between the self and the world, an thus brings about the unity of 'Ich' and 'Welt'. ${ }^{13}$ With this broad formulation, Buber also severs the mystical experience from belief in God, although the majority of the mystics he quotes did regard their experience as bringing them closer to God. Buber suggests that the belief in God may simply be a stage in the development of religion. The myths presented by particular religions, and by religious thinkers among whom Buber includes Plato and Jesus, may be symbols for the

\footnotetext{
${ }^{10}$ Elisabeth Stopp, 'Musil's Törleß: Content and Form', Modern Language Review, 63 (1968), 94-118 (p. 107).

${ }^{11}$ Musil, Törless, pp.181-82.

${ }^{12}$ Martin Buber, Ekstatische Konfessionen, in Werkausgabe, 2.2, ed. by David Groiser (Gütersloh:

Gütersloher Verlagshaus, 2012), p. 51.

${ }^{13}$ Buber, Ekstatische Konfessionen, p. 50.
} 
experience of ecstasy, which is in turn 'a revelation of the ultimate reality of being' ${ }^{14}$ Buber thus belongs to the turn-of-the-century movement away both from religious particularism and from rationalism, and towards 'godless mysticism'. No particular religious denomination, culture, or tradition is to be privileged: Buber and his contemporaries were seeking a kind of experience that is universal, and occurs in different guises in many cultures.

However, Buber's account invites a number of sceptical questions. First: in removing the religious content from mysticism, does he not run the risk of voiding it of any content at all? It becomes an experience, one which is rich and profound, but which one cannot say anything about and which one cannot integrate into one's life. Second: does not Buber reduce the variety of experiences that can be called 'mystical' by assimilating them all to the category of 'ecstasy'? Even in his own collection, the rapt contemplation of Plotinus differs markedly in tone from the intense and erotically charged experiences that St Teresa recounts to her confessor, and both are different again from the 'sense of the numinous', with its element of holy dread and awe, discussed at the same period by Rudolf Otto in Das Heilige (1917). ${ }^{15}$ Third: Buber assumes that the experience of mysticism is transitory, that it stands out clearly against the mundane majority of one's experience, and that it cannot be integrated into any system of cause and effect - what Buber disparagingly calls a 'Getriebe' or mechanism. ${ }^{16}$ But if one wants to make sense of one's life, may one not at least try to integrate a mystical experience into one's biography? Must it not be furthered in some way by the course of one's previous life, and may it not have an effect on one's future life, even if the preconditions and the effects remain partially obscure? The efforts in Catholic Christianity and in the great religions of Asia to make mysticism into a spiritual discipline presuppose some such continuity. And fourth: Buber assumes that mystical experience is solitary. The mystic's union of self and world depends on separation from other people and on immersion in the depths of the self. But may there not sometimes also be a communal element of mysticism? And can it be that Buber's account of mystical experience as solitary depends on a prior conception of the solitary self which can be traced back to Descartes but was emphatically not shared by the medieval mystics? ${ }^{17}$

To substantiate these doubts in some measure, perhaps I may be permitted to report an experience of my own. I will present it, detached by quotation marks from my main text, like the testimonies of religious experience quoted so copiously by William James.

'It was some time in the late 1990s, when I was more closely involved with the Church of England than I am now, that I attended, with a number of people from the same congregation, a half-day retreat, held in a house reserved for this purpose in a quiet street in North Oxford. It was a sunny day in late spring. At mid-morning we gathered in an upstairs room with an open window, outside which a large magnolia tree was in full flower. We sat, some fifteen of us, in a large circle round the edges of the room. After an opening prayer, we went into silent meditation.

'Almost immediately, the half-dozen or so themes that normally occupied my thoughts - relations with other people, teaching, writing, sexual fantasies, and so forth

\footnotetext{
${ }^{14}$ Buber, Ekstatische Konfessionen, pp. 58-59.

${ }^{15}$ Rudolf Otto, The Idea of the Holy, trans. by John W. Harvey (London: Oxford University Press, 1923).

${ }^{16}$ Buber, Ekstatische Konfessionen, p. 52.

${ }^{17}$ This argument is fully developed in Ben Morgan, On Becoming God: Late Medieval Mysticism and the Modern Western Self (New York: Fordham University Press, 2013).
} 
- instantaneously presented themselves to my mind, almost as concrete, visible objects, and then fell away. I was left with emptiness. But it was a full, rich, satisfying, welcome emptiness. I cannot say that it was an experience of anything. It was not bound up with any emotions, except contentment and some surprise. The presence of other people was in some way essential to the experience, and so was the magnolia tree outside the window.

'We continued in silence for about three-quarters of an hour and were then gently roused with the help of another prayer. We went downstairs for lunch. Everyone seemed to be under a spell, as I felt myself to be. Ordinary conversation was impossible. After lunch I walked in the garden, where other people were sitting quietly by themselves, and then went into the library and read the whole of St Mark's Gospel. At about three in the afternoon we all went our separate ways and returned to normal life. The return was in no way painful or discordant. The experience seemed to come to a natural end.

'I have never had such an experience since. I have neither sought it nor missed it. But it has left me convinced that William James is right in saying that "our normal waking consciousness, rational consciousness as we call it, is but one special type of consciousness, whilst all about it, parted from it by the flimsiest of screens, there lie potential forms of consciousness entirely different". ${ }^{18}$,

\section{A Rational Approach to the Non-Rational}

After publishing Törless, Musil, over the following years, thought hard about mysticism and how to understand it. He read extensively in the works of the great mystics of various cultures. As Genese Grill has recently summed up: 'An avid student of various forms of mysticism, Musil, the former engineer-physicist, had notebooks filled with notes and transcriptions of Meister Eckhart, Farid Ud-din Attar, Mechthild von Magdeburg, St. Theresa, Nicolas of Cusa, Lao-Tse, Rumi,

Ramakrishna, Novalis, Swedenborg, Maeterlinck, and numerous other mystic thinkers - ancient, medieval, modern, Eastern and Western. ${ }^{19}$ He especially read the anthology of mystical writings from around the world assembled by Martin Buber under the title Ekstatische Konfessionen. However, the striking feature of Musil's mature preoccupation with mysticism is that he does not focus on epiphanies, such as Törless's brief experience of infinity, or on brief ecstatic experiences, but increasingly contemplates the possibility of a lasting mystical state, which he refers to by the now well-known term 'the other condition' ('der andere Zustand').

As a preliminary to understanding mysticism, Musil distinguishes between two domains of experience. In 1918, apologising for the ugly neologism, he calls them the 'ratioide' and the 'nicht-ratioide' domain. This is not equivalent to rational vs. irrational. The 'ratioid' is the domain of the quantifiable and unequivocal. It is concerned with rules, though it acknowledges exceptions. It is necessary. But it is quite different from the 'non-ratioid'. The latter is concerned with exceptions to the rules, with unique, unclassifiable phenomena: 'it is the area of the individual's reactivity to the world and other individuals, the realm of values and valuations, of

\footnotetext{
18 James, Varieties, p. 388.

${ }^{19}$ Genese Grill, 'The "Other” Musil: Robert Musil and Mysticism', in A Companion to the Works of Robert Musil, edited by Philip Payne, Graham Bartram, and Galin Tihanov (Rochester, NY: Camden House, 2007), pp. 333-54 (p. 333).
} 
ethical and aesthetic relationships, the realm of the idea. ${ }^{20}$ Thus this domain is dialogical. Its phenomena arise in the interplay between people and their environments, and are consequently of an infinite subtlety. 'In this realm the comprehension of every judgment, the meaning of every concept, is surrounded by a delicate envelope of experience as by an ether, by a personal free choice and, alternating with it every few seconds, a personal determinism.' ${ }^{21}$ (PS 64).

In The Man without Qualities, of which the first volume was published in 1930, Musil created a protagonist, Ulrich, who practises an approach to experience called 'essayism' that is both experimental and rigorous. Far from being reductive, Musil employs a wealth of metaphor to capture the most fleeting emotional nuances. In this great novel, Musil renounces narrative order in favour of a leisurely satirical portrayal of social life in pre-war Vienna, interspersed with essayistic reflections. The novel's unity comes from the figure of Ulrich, who in August 1913 resolves to take a year's holiday from life and passively observe. He is drawn into the preparations for a "Parallelaktion" which plans to celebrate in 1918 the seventieth anniversary of the Emperor Franz Joseph's accession to the throne (parallel to the simultaneous thirtieth anniversary of the accession of the relatively upstart Wilhelm II of Germany). Unlike the reader, the characters cannot know that their plans are futile, so the progress of history is ironised from the outset.

An alternative dimension is introduced by Ulrich's 'Möglichkeitssinn' (sense of possibility), which he fosters to counteract the much-praised, normal

'Wirklichkeitssinn' (sense of reality); it allows him to envisage that things might always be different, and helps him to be suspicious of established constructions of reality. ${ }^{22}$ A trained mathematician (like Musil), he wants to apply scientific precision to such impalpable realities as mystical experience. He practises an approach to experience called 'essayism' that is both experimental and rigorous.

Around Ulrich there are many varieties of cod mysticism. All kinds of frauds want to indulge their souls. His cousin, Frau Tuzzi, known as Diotima, talks at great length about her soul ('Seele'), but Musil suggests that this is code for the emotional frustration resulting from her marriage to a worthy but stolid bureaucrat: 'What she called "soul" was probably nothing more than a small amount of capital in love she had possessed at the time of her marriage. Section Chief Tuzzi was not the right business opportunity to invest in.' (M107). The polymathic German millionaire Arnheim, who gradually slides into a love affair with her, talks about all aspects of the modern world with an ultimately phoney fluency and with equal interest, so that he can talk airily about the fusion of interests between business and the soul. Ulrich's friend Walter, a dilettante musician and painter, longs for the simple life as an escape from the degeneracy of Europe (61-2). He and his wife Clarisse look to music, especially Wagner, for an intoxication that lifts them above their unsatisfying daily lives, and mistake their emotional turmoil for the 'language of the eternal' (M 151).

\footnotetext{
${ }^{20}$ Robert Musil, Precision and Soul: Essays and Addresses, tr. David S. Luft and Burton Pike (Chicago: University of Chicago Press, 1990), p. 63. For the original, see 'Skizze der Erkenntnis des Dichters' in Musil, Gesammelte Werke, ed. by Adolf Frisé, 2 vols in 9 (Reinbek bei Hamburg: Rowohlt, 1978), vol. 2, pp. 1025-30.

${ }^{21}$ Musil, Precision and Soul, p. 64.

${ }^{22}$ See the chapter 'Wenn es Wirklichkeitssinn gibt, muß es auch Möglichkeitssinn geben', in Musil, Gesammelte Werke, vol. 1, pp. 16-18; 'If there is a sense of reality, there must also be a sense of possibility', in Musil, The Man Without Qualities, tr. Sophie Wilkins and Burton Pike (New York: Picador, 1995), pp. 10-13. Future quotations from this translation are identified in the text as M and page number.
} 
All the characters seek 'Rückkehr zu den inneren Urtümern' (I 249), ${ }^{23}$ an untranslatable phrase whose mockery of popular clichés is inevitably lost in 'a return to inner primal values' (M 269). They reject precise knowledge as unspiritual:

'Science had begun to be outdated, and the unfocused type of person that dominates the present had begun to assert itself' (M 269).

Musil despised this woolly attempt at spirituality. He thought that the spiritual life could be experienced and analysed with as much precision as mathematics. In other words, he opposed the modern reduction of mysticism to 'experience' instead of cognition. But in doing so, he had no wish to explain mysticism away by rationalising it. The many mystical testimonies make clear that what Musil called 'the other condition', 'der andere Zustand', is real and has been experienced by many people in a variety of forms. To approach this area of experience, Musil suggests that we modify the categories in which we think about the world.

In The Man Without Qualities Musil distinguishes between 'Eindeutigkeit' and 'Gleichnis', rendered by his most recent translators as 'single-mindedness' and 'metaphor':

Single-mindedness is the law of all waking thought and action, as much present in a compelling logical conclusion as in the mind of the blackmailer who enforces his will on his victim step by step, and it arises from the exigencies of life where only the single-minded control of circumstances can avert disaster. Metaphor, by contrast, is like the image that fuses several meanings in a dream; it is the gliding logic of the soul, corresponding to the way things relate to each other in the intuitions of art and religion. But even what there is in life of common likes and dislikes, accord and rejection, admiration, subordination, leadership, imitation, and their opposites, the many ways man relates to himself and to nature, which are not yet and perhaps never will be purely objective, cannot be understood in other than metaphoric or figurative terms (M 647). ${ }^{24}$

These two domains are not necessarily opposed. For 'Gleichnisse' or metaphors can be used with precision. Ulrich, getting over-excited, proposes that the Parallelaktion should establish a 'World Secretariat for Precision and Soul', in which the phenomena of the soul should be described with the precision conventionally associated with mathematics yet possible also in the language of poetry (M 651). That description is part of Musil's project.

\section{Transcendence in the Everyday}

Suppose, however, that mystical experience, based on the soul, could not only be described but incorporated more thoroughly into human life? Supposing mysticism were not a matter of brief epiphanies but a durable 'other condition'? Supposing that mysticism consisted not in transcending the everyday, but in transcendence in the everyday?

In The Man Without Qualities, mysticism has an erotic element, though it cannot be reduced to the erotic. Musil excels in social comedy, but his social comedy often has erotic undercurrents. His particular gift is to express the erotic charge that develops between to people who are attracted to each other. The novel's narrative

\footnotetext{
${ }^{23}$ Musil, Gesammelte Werke, vol. 1, p. 249.

${ }^{24}$ See Musil, Gesammelte Werke, vol. 1, p. 593.
} 
drive comes from this gradual build-up of erotic attraction among the characters - the attraction between Diotima and the German poseur Arnheim, Clarisse's and Gerda's desire for Ulrich, and above all the attraction between Ulrich and his long-lost sister Agathe, whom he meets for the first time in their adult lives when she joins him in arranging their father's funeral.

In Part Three of the novel, entitled 'Ins Tausendjährige Reich' ('Into the Millennial Kingdom'), Musil's social comedy becomes an intermittent background to two contrasting attempts to transcend everyday reality by making mystical experience into a prolonged condition.

The unstable Nietzschean Clarisse enthuses about redemption through murder and madness. She regards the murderer as an exceptional person. She urges her husband to kill his friend Ulrich because that will weaken the conscience which is fatal to his art: 'An artist can't make good music when he's saddled with a conscience!' (M 669). She is especially fascinated by the sex-murderer Moosbrugger, but is treated with appropriate irony. She wants to bear Ulrich a child who shall be the 'redeemer of the world' (M 720), and has chosen Ulrich for this mission because she considers him more of a barbarian than her husband.

Clarisse's high-flown fantasies form a demonic counterpart to the attempts made by Ulrich and his long-lost sister Agathe to sublimate sibling love into mysticism. Ulrich meets his sister again for the first time since their childhood. He has the strange feeling of identity with her: 'He felt as if it were his own self that had entered through a door and was coming to meet him, though it was a more beautiful self, with an aura in which he never saw himself. For the first time it flashed upon him that his sister was a dreamlike repetition and variant of himself' (M 754). He feels that she is his other self. Although they are not the same age, they feel like twins. They form a kind of androgynous couple, each supplementing the other.

Ulrich and Agathe explore mysticism in a manner that contrasts mysticism with morality. They first overstep the bounds of morality in dealing with their father's body before his funeral. They disregard their father's will by removing his decorations with which he wanted to be buried; and Agathe slips a garter, a symbol of sexuality, into the pocket of the dead man's coat. In doing this, Agathe displays a kind of innocence which is beyond good and evil and which takes even Ulrich aback:

'Agathe had a way of doing wrong that undercut any awareness of wrongdoing' (M 766).

Their practical disregard of morality leads into theoretical discussions about morality and its limitations. These are conducted especially in two chapters entitled 'Holy Conversations'. The starting-point is Agathe's only seemingly naïve question about goodness: 'Isn't it good to be good?' (M 812) The original formulation - 'Ist Gutsein denn nicht gut? ${ }^{25}$ - better conveys what is at issue. Being good is imagined as a state, a condition. In such a state, one ought to feel pleasure and satisfaction (though certainly not smug self-satisfaction). Yet people who practise morality rarely seem to be in such a state - least of all Agathe's husband, Professor Hagauer, an idealist philosopher and strict moralist, whom she has come to detest. 'A good person is one who has good principles and who does good things: it's an open secret that he can be quite disgusting as well.' (M 812)

Why this contradiction? Ulrich reflects that something has gone wrong with our conception of morality: 'Our morality is the crystallization of an inner movement that is completely different from it' (M 813). That is, we have an inner impulse that

\footnotetext{
${ }^{25}$ Musil, Gesammelte Werke, vol. 1, p. 747.
} 
presses us towards goodness, but we try to transform this impulse into a set of rules and prescriptions for being good, and following these rules produces only moral correctness, not the simple satisfaction of 'Gutsein' that Agathe and Ulrich want. Morality also leads people to utter statements such as 'Prison is a place for repentance' which common sense and common experience show to be absurd (M 813).

As a guide to 'Gutsein', Ulrich is reading mystical texts. These texts satisfy his scientific intellect because they are not vague or woolly. He finds that 'hat these believers have to say about their souls' adventures [...] is sometimes written with the force and the ruthless analytic conviction of a Stendhal' (M 819). That only applies, however, so long as the mystics confine themselves to a phenomenological description of their experiences. When they try to explain their experiences, they bring in God, and, what is worse, the flattering belief that God has singled them out for a communication. Yet they never manage to report what God said to them. 'It's an everlasting pity that no trained scientists have visions!' Ulrich concludes (M 820).

Ulrich thinks it quite possible that he might have an experience such as the mystics describe, without having either to believe in God or to sacrifice his rational consciousness. The phenomenological character of the experience would correspond to the accounts by mystics, but the self-flattering belief in God, and belief in receiving special favour from God, would be absent. The experience would be as real, as open to analysis, as any other psychological experience. Hence, when Agathe asks him about his reading, Ulrich says: 'I'm instructing myself about the ways of the holy life' (M 815) and adds: 'I'm not religious; I'm studying the road to holiness to see if it might also be possible to drive a car on it!' (M 815)

The siblings are thus in search of a mystical experience which is free both from morality and from belief in God, but which is not irrational or incomprehensible. They imagine it not as a brief epiphany but as a continuing state. Hence Agathe, excitedly following her brother's arguments, reinterprets the commandments of the gospels as expressions of such a state: "'Love thy neighbor!" doesn't mean love him on the basis of what you both are; it characterizes a dream state!' (M 828). In this dream state ('Traumzustand') it would be possible to feel a kind of love that transcends individuality and depends neither the kind of person I happen to be, nor on the personality of my neighbour. Ulrich agrees that the unwitting purport of all moral propositions is such a dream state, lying beyond good and evil. Mystical testimonies prove the possibility of such a state; it occurs within all the great religions, and is more ancient than the religious superstructures built on it. However, organised religion has always been suspicious of mysticism, as Ulrich says: 'the churches, that is, civilised communities of religious people, have always treated this condition with the kind of mistrust a bureaucrat feels for the spirit of private enterprise' (M 832). After all, why should a Church exist at all if individuals can attain this state without its supervision? And so the Churches have always done their best to control and suppress mysticism and to replace it with a set of moral rules which ostensibly guide people towards blessedness but in fact render the attainment of such a state impossible.

To convey how the possibility of the 'other condition' lurks uneasily on the edge of our civilisation, Ulrich continues by imagining a bureaucrat on holiday. Relaxing in an Alpine meadow, the bureaucrat may think of his normal life as distant and relatively unimportant. But when his holiday ends, he will return to his office and his family and be quite convinced that they constitute his real life. His detachment from them was only a holiday mood. Mysticism, on the other hand, would be a 
permanent holiday ('Dauerferien'). ${ }^{26}$ It would place the everyday world at a distance, and keep it there. At present, however, such experiences are commonly dismissed and medicalised as 'Wahn' - madness or delusion. ${ }^{27}$ We keep them covered up, like a suspect well, but their influence somehow undermines all the ideals that our civilisation officially upholds.

The siblings do not simply reflect on the possibility of mysticism as a prolonged condition; they actually experience it. The draft chapters entitled 'Beginning of a series of wondrous experiences' ('Beginn einer Reihe wundersamer Erlebnisse') and 'Moonbeams by sunlight' ('Mondstrahlen bei Tage') evoke a mystical experience which, unlike most mystical experiences, is not solitary but shared. The first of these chapters recounts how, as Agathe and Ulrich are putting on formal clothes to go out to a party, brief physical contact transports them to the mysterious other state they have so long been discussing. They do not go to the party, but neither do they increase their physical intimacy, as one might expect. They remain in a state of suspended intimacy or deflected sexuality.

This state finds expression in words, but not those of everyday speech: the moon -

Ulrich said without thinking, the way one talks into thin air: 'You are

Agathe understood.

Ulrich said: 'You have flown to the moon and it has given you back to me again -

Agathe said nothing: moon conversations so consume one's whole heart.

Ulrich said: 'It's a figure of speech. "We were beside ourselves," "We exchanged bodies without even touching each other," are metaphors too! But what does a metaphor signify? A little something true with a good deal of exaggeration. And yet I was about to swear, impossible as it may be, that the exaggeration was quite small and the reality was becoming quite large!'

He said no more. He was thinking: 'What reality am I talking about?' (M 1178-79)

This shows one of Musil's difficulties in writing about the other state of consciousness: that it cannot be put into words. At most, one can talk about it in elliptical, paradoxical language which makes no sense in everyday terms, as Ulrich does here. Or one can use striking imagery which makes the reader momentarily glimpse part of the world in a new light, as when Musil speaks of 'tender feelings that ream out the very marrow to form a flute!' (M 1180).

Mysticism is the sublimation of emotions and a new way of looking at the world: 'The weather had turned summery again, and they spent a lot of time outdoors: flowers and shrubs were blooming in the garden. When Ulrich looked at a blossom which was not exactly an ingrained habit of this once-impatient man - he now sometimes found no end to contemplation and, to say it all, no beginning either' ( $M$ 1183). Musil makes clear that this is not what commonly passes for nature-mysticism: 'Ulrich despised this cut-rate mysticism of the cheapest price and praise, whose constant preoccupation with God is at bottom exceedingly immoral; he preferred instead to continue abandoning himself to the dizziness of finding the words to

\footnotetext{
${ }^{26}$ Musil, Gesammelte Werke, vol. 1, p. 767.

${ }^{27}$ Musil, Gesammelte Werke, vol. 1, pp. 767-68. The translation of 'Wahn' as 'mania' (M 833) has an inappropriate suggestion of violent insanity.
} 
characterize a colour distinct enough to reach out and take hold of, or to describe one of the shapes that had taken to speaking for themselves with such mindless compellingness. For in such a condition the word does not cut and the fruit remains on the branch, although one thinks it already in one's mouth: that is probably the first mystery of day-bright mysticism' (M 1184).

In the chapter 'Atemzüge eines Sommertags' ('Breaths of a Summer Day'), on which Musil was working the day he died, Agathe has the most thorough-going mystical experience. She first recalls the mystical writers she and Ulrich have read: 'Other maxims too that she had recalled to his mind occurred to her: "Are you it, or are you not it? I know not where I am; nor do I wish to know!" "I have transcended all my abilities but for the dark power! I am in love, and know not in [with] whom! My heart is full of love and empty of love at the same time!" Thus echoed in her again the laments of the mystics, into whose hearts God had penetrated as deeply as a thorn that no fingertips can grasp. [...] Time stood still, a thousand years weighed as lightly as the opening and closing of an eye; she had attained the Millennium: perhaps God was even allowing his presence to be felt. And while she felt these things one after the other - although time was not supposed to exist anymore - and while her brother, so that she should not suffer anxiety during this dream, was beside her, although space did not seem to exist any longer either: despite these contradictions, the world seemed filled with transfiguration in all its parts' (M 1328). ${ }^{28}$

Musil's representation of 'the other condition' emerges naturally from his depiction of social interaction. Hence the question often raised by commentators - if Musil had finished the novel, would Ulrich and Agathe have slept together? - is misguided as well as trivial. The sublimation of their mutual erotic attraction gives rise to the mystical experiences they undergo. Hence Musil's mysticism is not an intervention from some other sphere. It is 'day-bright mysticism', 'taghelle Mystik', available within our world; it can be shared by Ulrich and Agathe, and can be prolonged. The transcendence it provides is a transcendence within the world. In that respect Musil, who was steeped in Nietzsche, remains within the spirit of Zarathustra's famous injunction: 'I beseech you, my brothers, stay true to the earth and do not believe those who talk of over-earthly hopes! They are poison-mixers, whether they know it or not.' 29

\footnotetext{
${ }^{28}$ This passage incorporates quotations from the narrative poem, The Conference of the Birds, by the twelfth-century Persian Sufi mystic Farîd-ed-dîn Attar, also known as Attar of Nishapur. See Buber, Ekstatische Konfessionen, pp. 75-76.

${ }^{29}$ Friedrich Nietzsche, Thus Spoke Zarathustra, trans. by Graham Parkes, Oxford World's Classics (Oxford: Oxford University Press, 2005), p. 12.
} 